\title{
Produksi dan Kualitas Jerami Padi Sumber Hijauan Pakan dengan Waktu Panen dan Dosis Pupuk Berbeda
}

Production and Quality of Rice Straw as Forage Sources with Different Harvest Time and Fertilizer Doses

\section{R Syafiyullah, N R Kumalasari*, L Abdullah}

Corresponding email: syafiyullah.radian@yahoo.com, nurku@apps.ipb.ac.id

Departemen Ilmu Nutrisi dan Teknologi Pakan, Fakultas Peternakan, IPB University, Jl. Agatis Kampus IPB Dramaga, Bogor, Indonesia

Submitted: $23^{\text {rd }}$ August 2021 Accepted : $2^{\text {nd }}$ December 2021

\section{ABSTRACT}

This study was aimed to analyze the fertilizer dosage and harvest age in Ciherang rice varieties to increase the rice straw production and quality. This study used a block randomized design with $3 \times 4$ blocks divided based on harvest age $\mathrm{H} 1=114$ days, $\mathrm{H} 2=$ 118 days and $\mathrm{H} 3=122$ days. The treatment was fertilizer dose level which consists of 4 levels, namely: P0 (control) = Urea 55 g+SP-36 5 g+KCl 6 g, P1= Urea 63,25 g+SP-36 $5 \mathrm{~g}+\mathrm{KCl} 6 \mathrm{~g}, \mathrm{P} 2=$ Urea 71,50 g+SP-36 $5 \mathrm{~g}+\mathrm{KCl} 6 \mathrm{~g}$ dan P3= Urea 79,75 g+SP-36 $5 \mathrm{~g}+\mathrm{KCl}$ $6 \mathrm{~g}$. The variables observed were straw production, grain production, filled grain production, empty grain production, crude protein (CP), crude fiber (CF), Acid Detergent Fiber (ADF) and Neutral Detergent Fiber (NDF). Data were analyzed using analysis of variance followed by Duncan's Multiple Range Test. The results showed that P3 was significantly $(\mathrm{p}<0.05)$ the highest among fertilizer dose level treatments on the straw production (27.63 tons ha-1), filled grain production (5.52 tons ha-1), and reduced empty grain ( 0.15 tons ha $\left.^{-1}\right)$. The Quality of rice straw were CP $7.49 \%$, CF $20.35 \%$, ADF $55.03 \%)$. While at harvest age, H1 was significantly $(\mathrm{p}<0.05)$ the highest among harvest ages treatments on the variables of straw production $28.18 \%$, empty grain production 0.21 tons $\mathrm{ha}^{-1}$ ) and NDF $69.11 \%$. It can be concluded that the best fertilizer dosage was an addition of urea by $45 \%$ with harvesting age of 114 days.

Key words: fertilizer, harvest age, production, quality, rice straw

\section{ABSTRAK}

Penelitian ini bertujuan untuk menganalisis level pupuk dan umur panen pada padi varietas Ciherang untuk meningkatkan produksi dan kualitas jerami padi pada masa panen padi yang direkomendasikan. Penelitian ini menggunakan rancangan acak kelompok 3 x 4 yang dikelompokkan berdasarkan umur panen H1=114 hari, H2=118 hari dan H3=122 hari. Perlakuan berupa level pupuk (P) yang terdiri dari 4 taraf, yaitu: $\mathrm{P} 0=$ Urea $55 \mathrm{~g}+\mathrm{SP}-365 \mathrm{~g}+\mathrm{KCl} 6 \mathrm{~g}, \mathrm{P} 1=$ Urea 63,25 g+SP-36 $5 \mathrm{~g}+\mathrm{KCl} 6 \mathrm{~g}, \mathrm{P} 2=$ Urea 71,50 g+SP-36 5 g+KCl 6 g dan P3= Urea 79,75 g+SP-36 5 g+KCl 6 g. Peubah yang diamati adalah produksi jerami, produksi gabah, produksi gabah isi, produksi gabah hampa, protein kasar (PK), serat kasar (SK), Acid Detergent Fiber (ADF) dan Neutral Detergent Fiber (NDF). Data dianalisis menggunakan sidik ragam (ANOVA) diikuti uji Jarak Berganda Duncan. Hasil penelitian menunjukkan penambahan urea 45\% meningkatkan produksi jerami $(27,63$ ton ha-1), produksi gabah isi $(5,52$ ton ha-1), dan mengurangi gabah hampa $\left(0,15\right.$ ton $\left.\mathrm{ha}^{-1}\right)$. Jerami mengandung PK 7,49\%, SK 20,35\%, ADF 55,03 \%). Kelompok umur panen 114 hari menunjukkan nilai tertinggi dibandingkan umur panen yang lain pada produksi jerami $28,18 \%$, produksi gabah hampa 0,21 ton ha-1 dan NDF 69,11\%. Dari penelitian ini dapat disimpulkan bahwa level pupuk terbaik pada penambahan urea sebesar 45\% dengan umur panen 114 hari.

Kata kunci: kualitas jerami, pupuk, produksi pasca panen, umur panen 


\section{PENDAHULUAN}

Padi merupakan tanaman pangan yang sangat banyak ditanam di Indonesia. Produksi padi 5,3 ton ha ${ }^{-1}$ dan produksi mencapai 75.397.841 ton per tahun (Badan Pusat Statistik 2015). Menurut Makarim et al. (2007) rasio produksi gabah dan jerami basah sebesar 2:3, sehingga pada tahun 2015 jerami padi yang dihasilkan sebesar 113.096.762 ton jerami basah per tahun, selain itu produksi jerami padi bervariasi antara 12-15 ton ha-1 satu kali panen tergantung jenis varietas dan lokasi tanam (Ahmad \& Nashir, 2008). Produksi jerami padi yang tinggi berbanding terbalik dengan kualitas yang rendah. hal itu disebabkan oleh serat kasar yang tinggi (lignin, selulosa, hemiselulosa) yang sulit dicerna (Wanapat et al. 2013). Beberapa penelitian menyebutkan bahwa jerami padi memiliki kandungan protein kasar 4,21-4,74 \%, serat kasar 24,76 \%-33,40 \%, lemak kasar 10,60\%, NDF 80,28 \% dan ADF 59,48\% (Amin et al. 2015; Basuni et al. 2015 ).

Salah satu cara memperbaiki kualitas jerami padi yaitu dengan mempercepat pemanenan sehingga menghasilkan kualitas yang lebih baik. Penentuan umur panen yang tepat sangat diperlukan untuk menjamin produksi yang tinggi dan kandungan nutrien yang memadai sebagai pakan ternak. Umur pemanenan dan pemberian pupuk padi merupakan salah satu faktor yang menentukan kualitas dari jerami padi supaya bisa meningkatkan kualitas nutrien. Astuti et al. (2018) menyatakan bahwa perlakuan umur panen 70 hari dengan pemupukan urea $200 \mathrm{~kg}^{-1}$ memiliki nilai tertinggi pada tinggi tanaman, hasil segar, hasil bahan kering dan hasil bahan organik.

Penelitian ini bertujuan untuk menganalisis umur panen dan level pemupukan pada padi varietas Ciherang untuk meningkatkan produksi dan kualitas jerami padi dalam periode umur panen padi yang direkomendasikan. Berdasarkan penjelasan sebelumnya maka perlu dilakukan penelitian tentang kualitas jerami padi untuk mengetahui pengaruh umur pemanenan dan pemberian pupuk dengan level yang berbeda terhadap kandungan nutrien dari jerami padi varietas ciherang.

\section{METODE}

\section{Waktu dan Tempat Penelitian}

Penelitian ini dilaksanakan pada bulan Juli-Desember 2020. Lokasi penanaman bertempat di sawah petani di Kecamatan Dramaga. Alat yang digunakan yaitu alat panen, timbangan digital, spuit $10 \mathrm{ml}$, alat semprot, pupuk dan benih.

\section{Prosedur Penelitian}

Benih varietas Ciherang sebanyak 0,5 kg direndam dalam ember untuk memisahkan antara yang berkualitas dan tidak berkualitas. Benih yang memiliki kualitas baik akan berada didasar sedangkan benih berkualitas kurang bagus akan mengapung dan harus dibuang. Perendaman dilakukan selama 1x24 jam hal ini dilakukan agar benih menyerap air yang cukup untuk proses perkecambahan. Proses penyemaian menggunakan nampan dengan campuran media tanah latosol dan pupuk kandang. Proses penaburan benih yang sudah berkecambah dengan lama waktu penyemaian selama 18 hari setelah itu dipindahkan ke lahan yang sudah disiapkan.

Luas lahan sawah petani $1000 \mathrm{~m}^{2}$, untuk lahan yang digunakan untuk pengambilan sampel penelitian terbagi 4 petak dengan masing-masing luas $1 \mathrm{~m} \times 2 \mathrm{~m}$. Lahan kemudian dicampur hingga homogen dengan pupuk kandang seberat $200 \mathrm{~kg}$. Pemindahan bibit dari tempat penyemaian ke lahan penelitian dilakukan saat bibit berumur 18 hari. Bibit ditanam sebanyak 3 bibit per lubang dengan jarak tanam $20 \mathrm{~cm}$ x $20 \mathrm{~cm}$. Pemberian pupuk sesuai dengan rekomendasi Kementerian Pertanian pada tahun 2017 berdasarkan spesifikasi lokasi Kecamatan Dramaga Kabupaten Bogor Provinsi Jawa Barat yaitu pupuk kandang 2 ton ha-1, urea $275 \mathrm{~kg}$ $\mathrm{ha}^{-1}$, SP-36 $25 \mathrm{~kg} \mathrm{ha}^{-1}$ dan KCL $30 \mathrm{~kg} \mathrm{ha}^{-1}$. Pemupukan dilakukan 2 kali, pemupukan pertama pada umur 25 HST dan pemupukan kedua pada umur 35 HST setelah penyiangan. Pemeliharaan dilakukan selama 122 hari dan penyiangan dilakukan sebelum pemupukan untuk menghindari adanya rerumputan atau gulma yang mengganggu pertumbuhan padi. Pengairan saat tanaman berumur 3 hari dengan tinggi genangan $3 \mathrm{~cm}$ selama 2 hari. Tanah dikeringkan pada 10-15 hari sebelum panen sampai saat panen. Pemanenan dilakukan 3 kali selama penelitian. Pemanenan dilakukan 2 hari lebih cepat dari umur rekomendasi untuk varietas Ciherang 116-125 hari (Badan Litbang Pertanian 2012). Pemanenan pertama dilakukan pada umur 114 hari, pemanenan kedua umur 118 hari dan pemanenan ketiga umur 122 hari dengan selang umur pemanenan 0,4 hari dan 8 hari.

\section{Peubah yang Diamati}

Peubah yang diukur dalam penelitian ini adalah produksi jerami, produksi gabah, produksi gabah isi, produksi gabah hampa, protein kasar, serat kasar, Acid Detergent Fiber dan Neutral Detergent Fiber.

Produksi jerami dihitung dengan cara menimbang langsung jerami padi setelah dilakukan pemanenan daun maupun batang, Selanjutnya produksi gabah ditimbang pada saat pemanenan. Produksi gabah hampa dan gabah isi didapatkan setelah memisahkan antara gabah hampa dan gabah isi dengan cara memilih satu persatu gabah hampa dengan gabah isi langsung setelah pemanenan.

Analisis kualitas jerami (protein kasar dan serat kasar) menggunakan metode proksimat (AOAC, 2005) sedangkan Acid Detergent Fiber (ADF) dan Neutral Detergent Fiber (NDF) menggunakan metode Van soest (1991).

\section{Rancangan Percobaan dan Analisis Data}

Penelitian ini menggunakan rancangan acak kelompok 3 x 4 yang dikelompokkan berdasarkan umur panen 
H1=114 hari, H2=118 hari dan H3=122 hari. Perlakuan berupa level pupuk (P) yang terdiri dari 4 taraf, yaitu: $\mathrm{P} 0=$ Urea $55 \mathrm{~g}+\mathrm{SP}-365 \mathrm{~g}+\mathrm{KCl} 6 \mathrm{~g}, \mathrm{P} 1=$ Urea 63,25 g+SP$365 \mathrm{~g}+\mathrm{KCl} 6 \mathrm{~g}, \mathrm{P} 2=$ Urea 71,50 g+SP-36 $5 \mathrm{~g}+\mathrm{KCl} 6 \mathrm{~g}$ dan P3= Urea 79,75 g+SP-36 5 g+KCl 6 g, setiap perlakuan 10 ulangan.

Data yang diperoleh dianalisis dengan menggunakan Analysist of Variance (ANOVA) menggunakan aplikasi SPSS versi 20. selanjutnya jika didapat hasil yang berbeda nyata dilakukan uji Duncan

\section{HASIL DAN PEMBAHASAN}

\section{Produksi Padi}

Produksi padi dalam penelitian ini meliputi: produksi jerami, produksi gabah, produksi gabah isi dan produksi gabah hampa tertera pada Tabel 1.

\section{Produksi jerami}

Pada penelitian ini tidak ada interaksi antara perlakuan pemupukan dan umur panen. Kelompok umur panen 114 hari menghasilkan produksi jerami yang tertinggi dibandingkan umur panen 118 dan 122 hari. Pemupukan berpengaruh nyata $(\mathrm{p}<0,05)$ terhadap produksi jerami padi. Produksi jerami tertinggi pada P3 dan yang terendah pada P0.

Tingginya produksi jerami padi P3 karena dosis pemupukan nitrogen yang diberikan tinggi maka akan menghasilkan anakan dan biomassa yang lebih banyak. Anhar et al. (2016) pemberian pupuk N yang tinggi pada awal pertumbuhan akan menyebabkan terbentuknya anakan yang akan meningkatkan biomassa jerami, sebaliknya apabila kandungan $\mathrm{N}$ tidak tercukupi maka pembentukan anakan akan terhenti. Unsur hara nitrogen sangat dibutuhkan untuk pertumbuhan vegetatif tanaman seperti daun, batang dan akar (Nuraeni et al. 2019).

\section{Produksi gabah}

Pada penelitian ini tidak ada interaksi antara perlakuan umur panen dan pemupukan. Kelompok umur panen tidak mempengaruhi produksi gabah dan gabah isi $(\mathrm{p}<0,05)$, namun mempengaruhi produksi gabah hampa. Pada pemanenan umur 114 hari produksi gabah hampa lebih tinggi dibandingkan tanaman padi dengan umur yang lebih tua. Pada perlakuan penambahan pupuk urea 45\% pemupukan mempengaruhi produksi gabah isi dan urea 15\% pada produksi gabah hampa.

Umur panen tidak berpengaruh nyata $(p<0,05)$ terhadap produksi gabah. Hal ini karena padi sudah berada pada fase generatif padi tidak memproduksi gabah melainkan proses pematangan bulir sedangkan produksi gabah berlangsung mulai pada fase vegetatif. Umur panen berpengaruh nyata $(p<0,05)$ terhadap gabah hampa. Berdasarkan perlakuan umur panen perlakuan $\mathrm{H} 2$ adalah perlakuan paling rendah produksi gabah hampa sedang perlakuan $\mathrm{H} 1$ dan H3 sama paling tertinggi.

Menurut Qibtiyah (2019), meningkatkan dosis urea maka meningkatkan produksi gabah, hal ini dikarenakan urea yang diberikan berfungsi untuk proses pembelahan sel tanaman sehingga berpengaruh terhadap produksi gabah. Penelitian Syakhril (2014) pemberian tambahan pupuk N saat tanaman padi Inpari Sidenuk yang berumur 40 hari setelah tanam dengan dosis urea $125 \mathrm{~kg} \mathrm{ha}^{-1}$ mampu meningkatkan hasil panen hingga 7,52 ton gabah kering panen ha-1 atau setara dengan 6,51 ton ha-1 GKG. Hal ini dikarenakan urea yang diberikan dalam jumlah yang lebih memberi pengaruh terhadap bertambahnya anakan baru sehingga meningkatkan pertumbuhan malai dan secara otomatis berpengaruh terhadap produksi gabah padi.

\section{Kualitas Jerami Padi Ciherang}

Kualitas jerami padi yang akan diberikan kepada ternak dapat dilihat dari kandungan protein kasar, serat kasar,

Tabel 1 Produksi jerami padi, produksi gabah, produksi gabah isi dan gabah hampa

\begin{tabular}{|c|c|c|c|c|c|c|}
\hline \multirow{2}{*}{ Variabel } & \multirow{2}{*}{ Umur Panen } & \multicolumn{4}{|c|}{ Level Pemupukan } & \multirow{2}{*}{ Total } \\
\hline & & $\mathrm{PO}$ & P1 & $\mathrm{P} 2$ & P3 & \\
\hline \multirow{4}{*}{$\begin{array}{l}\text { Produksi jerami } \\
(\text { ton ha-1) }\end{array}$} & $\mathrm{H} 1$ & $30,47 \pm 9,26$ & $27,72 \pm 7,31$ & $25,95 \pm 6,94$ & $28,54 \pm 7,36$ & $28,18 \pm 7,61^{a}$ \\
\hline & $\mathrm{H} 2$ & $14,22 \pm 6,12$ & $27,25 \pm 8,57$ & $17,10 \pm 3,73$ & $22,31 \pm 8,95$ & $20,30 \pm 8,61^{c}$ \\
\hline & $\mathrm{H} 3$ & $21,13 \pm 5,74$ & $22,09 \pm 8,71$ & $23,73 \pm 6,35$ & $32,55 \pm 6,50$ & $24,75 \pm 7,98^{b}$ \\
\hline & Total & $21,65 \pm 9,59 c$ & $25,74 \pm 8,33^{\mathrm{ab}}$ & $22,31 \pm 6,78^{b c}$ & $27,63 \pm 8,57 a$ & \\
\hline \multirow{4}{*}{$\begin{array}{l}\text { Produksi gabah } \\
(\text { ton ha-1) }\end{array}$} & $\mathrm{H} 1$ & $5,31 \pm 3,54$ & $4,68 \pm 2,26$ & $3,58 \pm 2,87$ & $6,31 \pm 1,89$ & $4,99 \pm 2,76$ \\
\hline & $\mathrm{H} 2$ & $3,62 \pm 2,31$ & $6,33 \pm 2,85$ & $3,93 \pm 2,79$ & $4,78 \pm 2,65$ & $4,68 \pm 2,76$ \\
\hline & $\mathrm{H} 3$ & $4,70 \pm 3,39$ & $4,30 \pm 3,72$ & $4,66 \pm 2,95$ & $5,69 \pm 3,14$ & $4,89 \pm 3,25$ \\
\hline & Total & $4,52 \pm 3,08$ & $5,10 \pm 3,03$ & $4,08 \pm 2,80$ & $5,69 \pm 2,58$ & \\
\hline \multirow{4}{*}{$\begin{array}{l}\text { Produksi gabah } \\
\text { isi } \\
\text { (ton ha-1) }\end{array}$} & $\mathrm{H} 1$ & $5,03 \pm 3,43$ & $4,43 \pm 2,21$ & $3,39 \pm 2,79$ & $6,13 \pm 1,83$ & $4,78 \pm 2,69$ \\
\hline & $\mathrm{H} 2$ & $3,47 \pm 2,20$ & $6,09 \pm 2,83$ & $3,79 \pm 2,78$ & $4,60 \pm 2,57$ & $4,50 \pm 2,70$ \\
\hline & $\mathrm{H} 3$ & $4,54 \pm 3,38$ & $4,04 \pm 3,60$ & $4,42 \pm 2,95$ & $5,87 \pm 3,12$ & $4,69 \pm 3,22$ \\
\hline & Total & $4,32 \pm 3,01^{a b}$ & $4,85 \pm 2,97^{a b}$ & $3,89 \pm 2,77^{b}$ & $5,52 \pm 2,54^{a}$ & \\
\hline \multirow{4}{*}{$\begin{array}{l}\text { Gabah hampa } \\
\text { (ton ha-1) }\end{array}$} & $\mathrm{H} 1$ & $0,25 \pm 0,13$ & $0,24 \pm 0,07$ & $0,18 \pm 0,13$ & $0,17 \pm 0,09$ & $0,21 \pm 0,11^{a}$ \\
\hline & $\mathrm{H} 2$ & $0,13 \pm 0,07$ & $0,24 \pm 0,09$ & $0,13 \pm 0,11$ & $0,13 \pm 0,11$ & $0,16 \pm 0,10^{b}$ \\
\hline & H3 & $0,16 \pm 0,08$ & $0,27 \pm 0,14$ & $0,21 \pm 0,12$ & $0,20 \pm 0,07$ & $0,20 \pm 0,12^{\mathrm{ab}}$ \\
\hline & Total & $0,18 \pm 0,11^{b}$ & $0,25 \pm 0,10^{a}$ & $0,17 \pm 0,12^{b}$ & $0,15 \pm 0,09^{b}$ & \\
\hline
\end{tabular}

P0 = Urea 55 g, SP-36 5 g, KCL 6 g; P1 = urea 63,25 g, SP-36 5 g, KCL 6 g; P2 = urea 71,50 g, SP-36 5 g, KCL 6 g; P3 = urea 79,75 g, SP-36 5 g, KCL 6 g; H1 = umur panen 114 hari; H2 = umur panen 118 hari; H3 = umur panen 122 hari; Superskrip yang berbeda pada kolom dan baris yang sama menujukkan perbedaan nyata $(\mathrm{p}<0,05)$ 
Tabel 2 Hasil analisis kualitas jerami padi Ciherang

\begin{tabular}{|c|c|c|c|c|c|c|}
\hline \multirow{2}{*}{ Variabel } & \multirow{2}{*}{$\begin{array}{l}\text { Umur } \\
\text { Panen }\end{array}$} & \multicolumn{4}{|c|}{ Level Pemupukan } & \multirow{2}{*}{ Total } \\
\hline & & PO & P1 & $\mathrm{P} 2$ & P3 & \\
\hline \multirow{4}{*}{$\begin{array}{l}\text { Protein Kasar } \\
(\%)\end{array}$} & $\mathrm{H} 1$ & $6,50 \pm 0,74$ & $6,87 \pm 0,49$ & $8,05 \pm 1,03$ & $6,88 \pm 1,22$ & $7,07 \pm 0,98$ \\
\hline & $\mathrm{H} 2$ & $6,40 \pm 0,49$ & $7,04 \pm 0,36$ & $7,82 \pm 0,77$ & $7,53 \pm 0,94$ & $7,19 \pm 0,81$ \\
\hline & $\mathrm{H} 3$ & $6,50 \pm 0,33$ & $7,03 \pm 0,18$ & $6,61 \pm 0,16$ & $7,05 \pm 1,13$ & $6,79 \pm 0,57$ \\
\hline & Total & $6,46 \pm 0,47^{b}$ & $6,97 \pm 0,32^{\mathrm{ab}}$ & $7,49 \pm 0,93^{a}$ & $7,15 \pm 0,99 \mathrm{ab}$ & \\
\hline \multirow[t]{4}{*}{ Serat Kasar (\%) } & $\mathrm{H} 1$ & $20,50 \pm 0,90$ & $19,17 \pm 0,44$ & $19,48 \pm 1,16$ & $20,71 \pm 0,48$ & $19,96 \pm 0,96$ \\
\hline & $\mathrm{H} 2$ & $20,94 \pm 0,93$ & $17,84 \pm 3,16$ & $20,91 \pm 0,62$ & $19,74 \pm 2,15$ & $19,85 \pm 2,14$ \\
\hline & $\mathrm{H} 3$ & $20,74 \pm 0,71$ & $20,09 \pm 0.84$ & $20,69 \pm 0,74$ & $20,62 \pm 0,50$ & $20,53 \pm 0,61$ \\
\hline & Total & $20,72 \pm 0,70^{a}$ & $19,03 \pm 1,91^{b}$ & $20,36 \pm 1,22^{\mathrm{a}}$ & $20,35 \pm 1,22^{\mathrm{a}}$ & \\
\hline \multirow{4}{*}{$\begin{array}{l}\text { Acid Detergent } \\
\text { Fiber }(\%)\end{array}$} & $\mathrm{H} 1$ & $54,94 \pm 0,29$ & $56,92 \pm 1,50$ & $55,68 \pm 0,87$ & $54,45 \pm 1,12$ & $55,50 \pm 1,31$ \\
\hline & $\mathrm{H} 2$ & $54,70 \pm 0,83$ & $58,06 \pm 1,01$ & $55,58 \pm 0,81$ & $54,55 \pm 0,83$ & $55,72 \pm 1,64$ \\
\hline & $\mathrm{H} 3$ & $57,61 \pm 0,50$ & $56,72 \pm 1,16$ & $54,32 \pm 1,47$ & $56,09 \pm 1,77$ & $56,18 \pm 1,68$ \\
\hline & Total & $55,75 \pm 1,48^{b}$ & $57,23 \pm 1,24^{a}$ & $55,19 \pm 1,15^{b}$ & $55,03 \pm 1,38^{b}$ & \\
\hline \multirow{4}{*}{$\begin{array}{l}\text { Neutral } \\
\text { Detergent Fiber } \\
\text { (\%) }\end{array}$} & $\mathrm{H} 1$ & $69,13 \pm 1,04$ & $70,43 \pm 0,98$ & $69,60 \pm 0,85$ & $71,06 \pm 0,97$ & $70,05 \pm 1,13^{a}$ \\
\hline & $\mathrm{H} 2$ & $70,52 \pm 1,02$ & $71,42 \pm 0,79$ & $71,29 \pm 0,95$ & $68,37 \pm 1,17$ & $70,40 \pm 1,52^{\mathrm{a}}$ \\
\hline & $\mathrm{H} 3$ & $66,05 \pm 1,66$ & $70,00 \pm 1,30$ & $69,51 \pm 0,81$ & $70,88 \pm 1,66$ & $69,11 \pm 2,22^{b}$ \\
\hline & Total & $68,56 \pm 2,26^{b}$ & $70,61 \pm 1,10^{a}$ & $70,13 \pm 1,15^{a}$ & $70,10 \pm 1,66^{a}$ & \\
\hline
\end{tabular}

P0 = Urea 55 g, SP-36 5 g, KCL 6 g; P1= urea 63,25 g, SP-36 5 g, KCL 6 g; P2= urea 71,50 g, SP-36 5 g, KCL 6 g; P3= urea 79,75 g, SP-36 5 g, KCL 6 g; H1 = umur panen 114 hari , H2 = umur panen 118 hari, H3 = umur panen 122 hari; Superskrip yang berbeda pada kolom dan baris yang sama menujukkan perbedaan nyata $(\mathrm{p}<0,05)$

ADF dan NDF (Tabel 2). Kelompok umur panen tidak berpengaruh nyata $(\mathrm{p}<0,05)$ terhadap kadar protein kasar dan serat kasar. Perlakuan pemupukan berpengaruh nyata $(\mathrm{p}<0,05)$ terhadap kandungan protein kasar, serat kasar dan ADF.

Kelompok umur panen tidak berpengaruh nyata $(\mathrm{p}<0,05)$ karena umur pemanenan yang sudah masuk fase generatif. Menurut Savitri et al. (2013), perkembangan umur tanaman hijauan akan terjadi pula peningkatan konsentrasi seratnya. Selain itu, semakin meningkat umur tanaman akan berkurang kandungan protein, mineral dan karbohidrat mudah larut serta meningkat kandungan serat kasar (Koten et al. 2012).

Menurut Tantalo (2019) umur panen yang terlalu lama akan meningkatkan serat kasar hijauan sehingga tanaman mempunyai komponen dinding sel yang tinggi. Kelompok umur panen 122 hari menunjukkan bahwa umur panen semakin lama ternyata menurunkan kadar NDF dalam jerami. Menurunnya kadar NDF pada jerami disebabkan meningkatnya kadar lignin yang mengakibatkan menurunnya kadar hemiselulosa. Hemiselulosa dan selulosa merupakan komponen dinding sel yang dapat dicerna oleh mikroba (Sudirman et al. 2015)

Penambahan urea pada penelitian ini meningkatkan kandungan protein kasar dan NDF karena penambahan pupuk meningkatkan kadar $\mathrm{N}$ dalam tanaman, sehingga

\section{DAFTAR PUSTAKA}

Ahmad M \& Nashir. 2008. Pembuatan jerami fermentasi. Lembar Informasi Pertanian (LIPTAN) IP2TP Mataram No.02/Liptan/2000. Mataram (ID): Instalasi Penelitian dan Pengkajian Teknologi Pertanian. Mataram.

Amin M, Hasan SD, Yanuarianto 0 \& Iqbal M. 2015. Pengaruh lama fermentasi terhadap kualitas jerami padi amoniasi yang ditambah meningkatnya takaran NPK majemuk diikuti dengan meningkatnya kadar $\mathrm{N}$ dan $\mathrm{P}$ tanaman (Purnomo 2008). Menurut Koten et al. (2012) meningkatnya pemberian urea maka semakin banyak pula $\mathrm{N}$ yang tersedia sebagai bahan baku pembentukan protein. Pada perlakuan P2 dan P3 semakin meningkat level pupuk yang diberikan semakin meningkat nilai serat kasar jerami. Hal ini berbeda dengan Nuraeni (2019) menyatakan bahwa kadar serat kasar mengalami penurunan dengan semakin meningkat taraf urea.

Perlakuan pemupukan menurunkan kandungan ADF pada perlakuan P2 dan P3 serta meningkatkan kadar NDF jerami. Hal ini mengindikasikan kualitas jerami yang cukup bagus karena semakin rendah fraksi NDF maka kecernaan pakan akan semakin tinggi. Nori et al. (2008) menyatakan dengan peningkatan pemberian pupuk nitrogen mengakibatkan penurunan ADF jerami padi.

\section{SIMPULAN}

Kelompok umur panen 114 hari menghasilkan produksi jerami tertinggi, menurunkan kadar NDF dan gabah hampa. Level pemupukan penambahan $45 \%$ pupuk urea meningkatkan produksi jerami, produksi gabah isi, protein kasar dan menurunkan nilai ADF.

probiotik Bacillus sp.Jurnal Ilmu dan Teknologi Peternakan Indonesia, 1(1) :8-13.

Anhar R, Hayati E, \& Efendi E. 2016. Pengaruh dosis pupuk urea terhadap pertumbuhan dan produksi plasma nutfah padi lokal asal Aceh. Jurnal Kawista Agroteknologi 1(1) : 30-36.

AOAC. 2005. Official Methods of Analysis of AOAC International. $18^{\text {th }}$ ed: Assoc. Arlington (US) : Off. Anal. Chem.,

Astuti D, Suhartanto B, Umami N, \& Agus A. 2018. Pengaruh dosis pupuk urea dan umur panen terhadap hasil hijauan sorgum (Sorghum 
bicolor (L) Moench). Agrotechnology Innovation (Agrinova), 1(2) 45-51.

Badan Litbang Pertanian. 2012. Varietas Padi Unggulan. Agroinovasi Sinartani Edisi 25-januari 2012 No.3441 tahun XLII

Badan Pusat Statistik. 2015. Produktivitas Padi Di Indonesia. Jakarta Dikutip 2 februari 2019

Basuni R, Muladno, M, Kusmana C \& Suryahadi S. 2015. Sistem Integrasi Padi-Sapi Potong di Lahan Sawah. Iptek Tanaman Pangan, 5(1) : 31-48

Koten B B, Soetrisno RD, Ngadiyono N, \& Suwignyo B. 2012. Produksi tanaman sorgum (Sorghum bicolor (L.) Moench) varietas lokal Rote sebagai hijauan pakan ruminansia pada umur panen dan dosis pupuk urea yang berbeda. Buletin Peternakan, 36(3), 150-155.

Makarim AK, Sumarno \& Suyamto. 2007. Jerami Padi: Pengelolaan dan Pemanfaatan. Bogor (ID): Pusat Penelitian dan Pengembangan Tanaman Pangan. Badan Penelitian dan Pengembangan Pertanian.

Nori H, Halim RA, \& Ramlan MF. (2008). The effects of nitrogen fertilization levels on the straw nutritive quality of Malaysian rice varieties. Journal of Agronomy 2(2):61-71

Nuraeni A, Khairani L, \& Susilawati I. 2019. Pengaruh tingkat pemberian pupuk nitrogen terhadap kandungan air dan serat kasar Corchorus aestuans. Pastura, 9(1) : 32-35.

Purnomo J. 2008. Pengaruh pupuk NPK majemuk terhadap hasil padi varietas Ciherang dan sifat kimia tanah inceptisol Bogor. Prosiding Seminar Nasional dan Dialog Sumberdaya Lahan Pertanian. Bogor (ID) : Balittanah.
Qibtiyah M. 2019. Efektifitas aplikasi waktu pemberian biourine plus dan dosis pupuk urea terhadap peningkatan pertumbuhan dan produksi padi (Oryza sativa L.). AGRORADIX: Jurnal Ilmu Pertanian 2(2) : 44-51.

Savitri M V, Sudarwati H, \& Hermanto H. 2013. Pengaruh umur pemotongan terhadap produktivitas gamal (Gliricidia sepium). Jurnal Ilmu-Ilmu Peternakan (Indonesian Journal of Animal Science) 23(2) : 25-35.

Sudirman S, Hasan SD, Dilaga SH, \& Karda IW. 2015. Kandungan neutral detergent fibre (NDF) dan acid detergent fibre (ADF) bahan pakan lokal ternak sapi yang dipelihara pada kandang kelompok. Jurnal Ilmu dan Teknologi Peternakan Indonesia, 1(1) : 77-81.

Syakhril R, \& Arsyad H. 2014. Pengaruh pupuk nitrogen terhadap penampilan dan produktivitas padi Inpari Sidenuk. Agrifor: Jurnal Ilmu Pertanian dan Kehutanan, 13(1) : 85-92.

Tantalo S, Liman L, \& Fathul F. 2019. Efek umur pemangkasan indigofera (Indigofera zollingeriana) pada musim kemarau terhadap kandungan Netral Detergen Fiber dan Acid Detergen Fiber. Jurnal Ilmiah Peternakan Terpadu, 7(2) : 241-246.

Van Soest PJ, Robertson JB \& Lewis BA. 1991. Methods for dietary fiber, neutral-detergent fiber and nonstarch polysaccharides in relation to animal nutrition. Journal of Dairy Science 74: 3583-3597.

Wanapat M, Kang S, Hankla N, \& Phesatcha K. 2013. Effect of rice straw treatment on feed intake, rumen fermentation and milk production in lactating dairy cows. African Journal of Agricultural Research 8(17) : 1677-1687. 